This document is the accepted manuscript version of the following article:

Bavay, M., Lehning, M., Jonas, T., \& Löwe, H. (2009). Simulations of future snow cover and discharge in Alpine headwater catchments. Hydrological Processes, 23(1), 94-108. https://doi .org/10.1002/hyp.7195

\title{
Simulations of Future Snow Cover and Discharge in Alpine Headwater Catchments
}

\author{
Mathias Bavay, Michael Lehning, Tobias Jonas, Henning Löwe*
}

September 22, 2008

Keywords: Climate Change, Catchment Hydrology, Water Resources, Flow Regime, Flooding, Snow Melt

\begin{abstract}
The snow cover in the Alps is heavily affected by climate change. Recent data show that at altitudes below $1200 \mathrm{~m}$ a.s.l. a time-continuous winter snow cover is becoming an exception rather than the rule. This would also change the timing and characteristics of river discharge in Alpine catchments. We present an assessment of future snow and runoff in two Alpine catchments, the larger Inn catchment $\left(1945 \mathrm{~km}^{2}\right)$ and the smaller Dischma catchment $\left(43 \mathrm{~km}^{2}\right)$, based on two common climate change scenarios (IPCC A2 and B2). The changes in snow cover and discharge are predicted using ALPINE3D, a model for the high resolution simulation of alpine surface processes, in particular snow, soil and vegetation processes. The predicted changes in snow and discharge are extreme. While the current climate still supports permanent snow and ice on the highest peaks at altitudes above $3000 \mathrm{~m}$ a.s.l., this zone would disappear under the future climate scenarios. The changes in snow cover could be summarized by approximately shifting the elevation zones down by $900 \mathrm{~m}$. The corresponding changes in discharge are also severe: while the current climate scenario shows a significant contribution from snow melt until mid to late summer, the future climate scenarios would feature a much narrower snow melt discharge peak in spring. A further observation is that heavy precipitation events in the fall would change from mainly snow to mainly rain and would have a higher probability of producing flooding. Future work is needed to quantify the effect of model uncertainties on such predictions.
\end{abstract}

${ }^{*}$ WSL Institute for Snow and Avalanche Research, SLF Davos, Flüelastr. 11, Davos Dorf, Switzerland

†emails: bavay, lehning, jonas, loewe @slf.ch 


\section{Introduction}

Model assessments of future climate impact have become a standard tool for translating climate change scenarios to the potential reaction of the environment. The reaction of the local hydrological balance is a particularly important question in this context. Understanding these changes may help to design appropriate adaptation strategies. Huge areas of the world depend on snow melt during the dry summer months, but climate change may lead to less snow and may severely aggravate existing water shortages (Barnett et al., 2005). Areas which fall under this regime are the western Americas, central Asia, northern India and parts of southern Europe. While the impact of changes in snow cover is global and affects large areas, much can be learned by studying the response in smaller headwater catchments. The purpose of this paper is therefore to present calculations of snow cover and runoff change scenarios for the second half of the 21st century for two headwater catchments in the central Alps: Dischma $\left(43 \mathrm{~km}^{2}\right)$ and Inn $\left(1945 \mathrm{~km}^{2}\right)$.

A number of model-based assessments have been made of the hydrological response of mountain catchments to climate change (e.g. Singh and Kumar, 1997; Stahl et al., 2008, Horton et al., 2006). These first quantitative results point in particular to the influence of shrinking ice masses. They show that pronounced effects are predicted for glaciated catchments, where high runoff levels shift from summer to spring because melt rates of the ice sheet decrease after a transitional phase of increased runoff (Stahl et al, 2008). In a glaciated catchment, a major effect, i.e. the disapearance of permanent snow cover for this particular catchment, has been found for the accumulation zone at higher altitudes (Magnusson et al., submitted). The role of the snow cover in runoff changes has been investigated less intensively with a few exceptions in North America (e.g. Stewart et al., 2005) and is the focus of our investigation. For the current study, we do not not attempt to discuss the different reasons for a change in snow cover such as change in snowline (Knowles et al., 2004) or change in melt in detail but instead concentrate on changes in the spatial patterns of snow cover distribution and temporal patterns of catchment discharge.

Massive changes of the mountain snow cover are expected and have already been detected (Marty, 2008). Trend analyses of changes in mountain snow covers have been carried out by Hantel et al. (2000), Laternser and Schneebeli (2003) and Scherrer et al. (2004) for the Alps and e.g. Hamlet et al. (2005) and Mote (2006) for North America. All studies agree that the most pronounced changes are detected for lower altitudes. This finding is consistent with the explanation that temperature trends are most visible at those elevations for which a small change in temperature leads to increased 
rain versus snow precipitation (change in snow line). To assess the overall effect of climate change on the seasonal snow cover, snow models have been used but investigations continue to be focused on individual point measurement stations only (Rasmus et al, 2004, Lòpez-Moreno et al., in press). There are thus two major reasons for additional model studies on the combined behavior of snow and discharge under climate change scenarios. First, a variety of models with different complexity and physics must be used to build confidence in the model projections. Second, the critical behavior of the snow cover needs to be assessed with respect to runoff formation by applying detailed snow models at a distribution of points across the catchment. The novel aspects of our approach are that, to our knowledge, no combined and detailed investigation of snow and discharge response to climate change scenarios for Alpine headwater catchments is available. We present a comparative analysis of catchments of two different sizes. More importantly, we use the advanced modeling system Alpine3D for our model runs, which provides a detailed process representation (Lehning et al., 2006) especially for snow (Lehning et al., 2002) and appears therefore particularly suited for change studies. Note that change studies require extrapolation from current conditions and therefore conceptual models, which require a high degree of calibration, may not always be the best choice for change prediction.

We will first describe the catchments and the numerical model used for this study. Then, the method for producing the meteorological data necessary for the model and the postprocessing applied to the simulation results will be described. The third section will verify the performance of the modelling approach by comparison to measured data from the current climate. The results of climate scenario calculations will be presented and discussed in the next section and the limitations of both the meteorological data processing and the physical modelling will also be discussed. Finally, implications of these results will be provided in the conclusion.

\section{Catchments and modeling}

\subsection{Description of catchments}

The first catchment simulated is Dischma, located in eastern Switzerland. It ranges in elevation from 1677 to 3130 meters above sea level and covers an area of $43.3 \mathrm{~km}^{2}$. The rectangular simulation domain encompassing the catchment covers a wider area of $12.8 \mathrm{~km}$ by $15.4 \mathrm{~km}\left(197 \mathrm{~km}^{2}\right)$. The catchment was described in detail by Zappa et al. (2003). Surface cover is $36 \%$ subalpine meadow and $34 \%$ rock, the rest being minor contributions from 


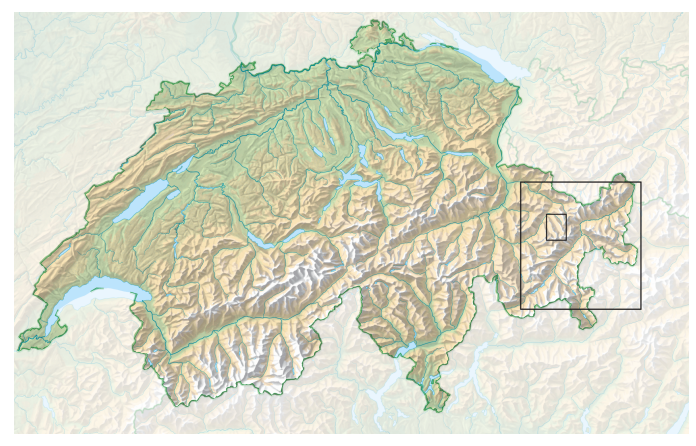

Figure 1: Location of the Dischma (small box) and Inn (large box) catchments.

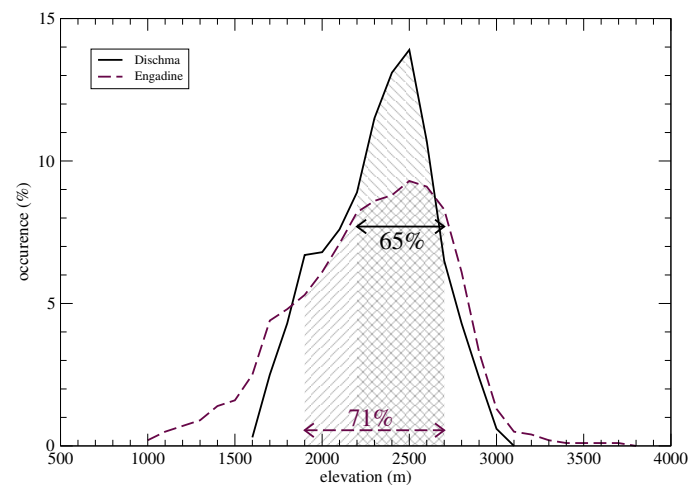

Figure 2: Vertical distribution of grid cells for the Dischma and Inn catchments areas used in the simulation.

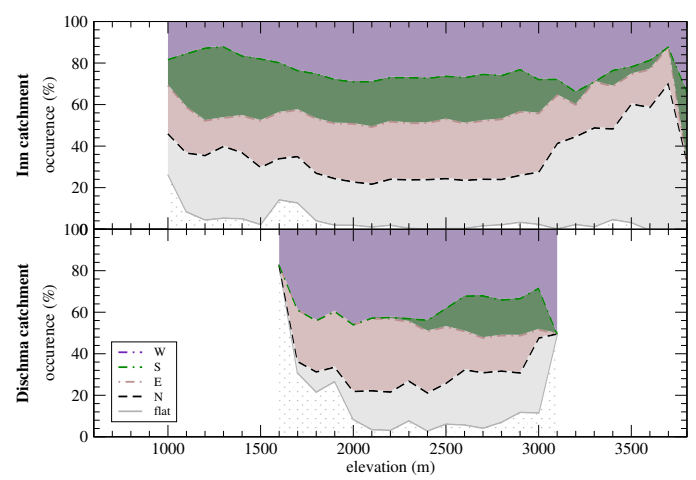

Figure 3: Distribution of the aspects of the cells in the Dischma and Inn simulations. 


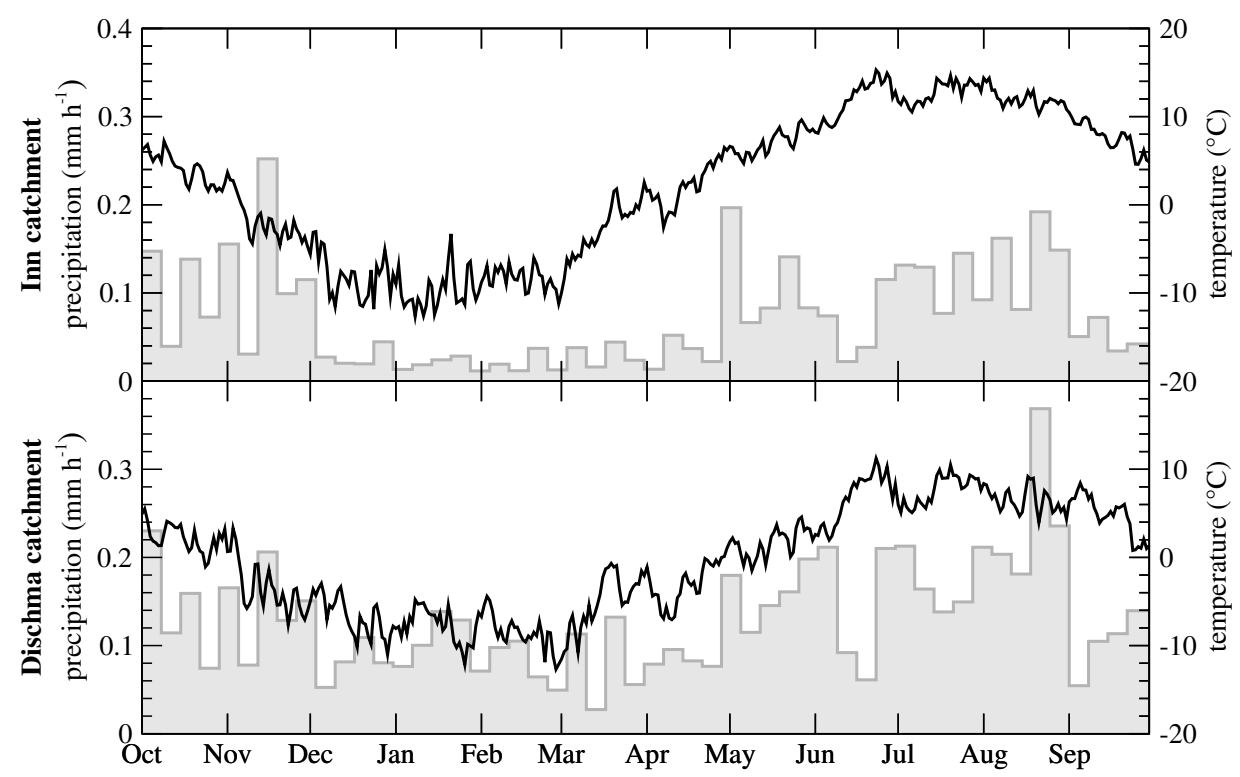

Figure 4: Measured daily averaged precipitation and temperature for the Dischma (Weissfluhjoch station, 2537 m a.s.l.) and Inn catchments (Samedan station, $1707 \mathrm{~m}$ a.s.l.) for winters 2002-2006.

forests and bushes. Glaciers do not play a significant role but are present in the simulated area ( $2 \%$ of the total area). The domain is meshed by $100 \mathrm{~m} \times 100 \mathrm{~m}$ square cells.

The Inn catchment occupies $1945 \mathrm{~km}^{2}$ within a $66.5 \mathrm{~km}$ by $71.75 \mathrm{~km}$ rectangular simulation domain $\left(4771 \mathrm{~km}^{2}\right)$. This domain also contains the Dischma catchment, which is however not part of the Inn catchment. The catchment has an altitude range from 1045 to 3868 meters above sea level. A few glaciers are part of the catchment (5\%) but again, most of the surface is rock (36\%) and sub-alpine meadow (20\%) with coniferous forests (13\%) also occupying a significant fraction. One of the best known Swiss glaciers, the Morteratsch, is part of the simulated area. The domain is meshed by $250 \mathrm{~m} \times 250 \mathrm{~m}$ square cells.

The distribution of the elevations for both catchments is shown in Figure 2. This figure shows the frequency of occurrence of a given $100 \mathrm{~m}$ altitude band in each catchment. Both catchments contain a major surface fraction in the elevation range between 2000 and $2700 \mathrm{~m}$ a.s.l.. When looking at the distribution of the aspects in Figure 3, one sees that the aspects are not evenly represented in the Dischma simulation, whereas the distribution is more even for the core of the Inn simulation. The over-representation of flat land for the first elevation range (1600 m a.s.l.) of the Dischma simulation means 
that the results for this elevation range will not correlate well to those of the similar altitude band in the Inn simulation. The different orientations of Dischma (mainly S-N) and Inn (mainly W-E) catchments may also produce differences in the hydrological response.

Finally, the average precipitation and temperatures for both catchments are shown in Figure 4. The temperatures are shown as daily averages, averaged again over the winters 2002-2006. Precipitation is shown as weekly and monthly averages, also averaged over the winters 2002-2006. This figure shows one of the major differences between these two catchments: the Inn catchment is much dryer than the Dischma catchment (on average $640 \mathrm{~mm} /$ year for the Inn catchment compared to $1138 \mathrm{~mm} /$ year for the Dischma catchment in our data set).

\subsection{The Alpine3d model}

Alpine3D is a model system of Alpine surface processes with an emphasis on snow processes. Since detailed model module descriptions and verifications are available from previous publications, we only offer a summary of the most important features here and point to the respective publications. The model is based on a fully distributed application of SNOWPACK (Lehning et al., 1999; Lehning et al., 2002), which is an advanced model of snow cover development. SNOWPACK has been used for studying snow dynamics in the context of avalanche warning (e.g. Nishimura et al., 2005), glacier mass balance and hydrology (e.g. Michlmayr et al.,2008) and already for climate change scenarios in high latitudes (Rasmus et al., 2004) and for Alpine permafrost (Luetschg et al. in press). The single point snow column description provided by SNOWPACK includes a parameterized module for vegetation. Snow and soil dynamics are numerically represented by a large arbitrary number of layers. The high resolution of the surface snow or soil layers allows a more accurate surface energy balance to be provided as well as allowing the vertical water transport in snow and soil to be described with a simple bucket scheme (Bartelt and Lehning, 2002).

In Alpine3D, atmospheric forcing is allowed to vary continously in space such that the one-dimensional vegetation - snow - soil columns at the grid points will also vary as a result. Runoff is calculated by a simple conceptual model, which is fed from the vegetation - snow - soil columns (Lehning et al., 2006). It is important to note that for climate change scenarios, one should also consider that vegetation and even soil would change. This could not be implemented for this study since predictions of these changes were not available. It is however assumed that the effects of changes in vegetation and soil will remain small compared to other model errors such 
as the interpolation of the meteorological forcing. By contrast, the changing climate is unlikely to change much of the deeper subsurface flow paths such that the assumption of stationarity appears to be justified for the conceptual runoff model. Michlmayr et al. (in press) gives a good introduction to the radiation module of Alpine3D, which supports shading, surface reflections of shortwave radiation and emission of longwave radiation.

The full version of Alpine3D uses meteorological input (wind, temperature, moisture) from a meso- or microscale meteorological model (Raderschall et al., 2008) and includes snow transport (Lehning et al., 2008). Because of the high resolution required and the associated immense computing capacity requirements, these detailed features have never been used for hydrological or climate studies.

\section{Methods}

\subsection{Reference meteorological data}

Hourly data from 10 weather stations in the Dischma and 18 stations in the Inn catchment, respectively were used as model input for establishing a reference run. The stations represent an altitude range from 1560 to $2725 \mathrm{~m}$ a.s.l. in the Dischma and 1078 to $3315 \mathrm{~m}$ a.s.l. in the Inn catchment. Temperature, humidity, wind speed and precipitation input data were distributed across the grid using WINMET (Zappa et al., 2003), a tool for geo-statistical interpolation of meteorological data. As an interpolation method we selected inverse distance weighting (Shepard, 1968) for all four input quantities in combination with elevation dependent detrending for temperature, humidity and wind speed but not for precipitation. For both catchments we used hourly measurements of incoming longwave radiation from the Weissfluhjoch station (2537 m a.s.l.) above Davos, $4 \mathrm{~km}$ north of the Dischma catchment outlet. For the Dischma catchment shortwave radiation was also taken from Weissfluhjoch whereas the Samedan meteorological station (1707 m a.s.l.) served as shortwave radiation input for the Inn catchment.

\subsection{RCM predictions}

To generate model input data representative of future climate, we altered observed data according to expected changes as predicted by a set of RCMs (Regional Climate Models) which participated in the PRUDENCE project (Prediction of Regional scenarios and Uncertainties for Defining European Climate change risks and Effects) (Christensen et al., 2007). Climate pre- 


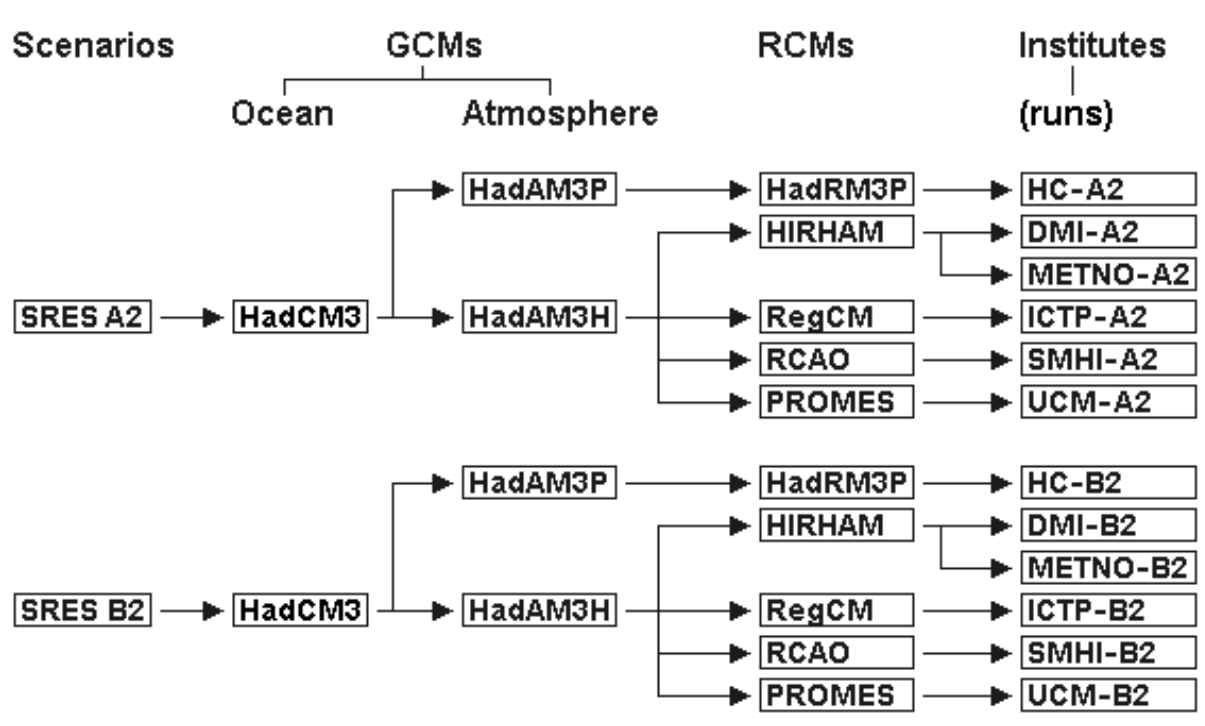

Figure 5: Basis of the 12 simulations for the future period 2071-2100: the RCMs, GCMs, and the scenarios. Accordingly, six reference simulations were performed for the reference period 1961-1990. Abbreviations according to PRUDENCE notation (http://prudence.dmi.dk/).

diction data resulting from this project are available from a public database (http://prudence.dmi.dk/). A subset of twelve runs (Fig 5) was selected to provide simulations for the changes in temperature, precipitation and longwave radiation between a reference period 1961-1990 and a future period 2071-2100 for the two IPCC greenhouse gas emission standard scenarios SRES A2 and B2. While scenario A2 predicts a strong increase of carbon dioxide, scenario B2 assumes a rather moderate rise of CO2 (Nakicenovic et al., 1998). The following 5 RCMs were used for the simulations: HIRHAM (used by the Danish and Norwegian Meteorological Institutes), PROMES (Universidad Complutense de Madrid), RCAO (Swedish Meteorological and Hydrological Institute), HadRM3P (Hadley Centre for Climate Prediction and Research) and RegCM (Abdus Salam Intl. Centre for Theoretical Physics). For the present study, we downloaded daily minimum and maximum temperatures, daily accumulated precipitation and daily averages of incoming longwave radiation. These parameters were expected to have the greatest influence on snowpack characteristics. Potential changes in relative humidity, wind speed and short wave radiation were assumed to be more uncertain and were therefore not taken into account. For each catchment, we used the data of the nearest grid cell from the RCM output (spatial resolution $\sim 50 \mathrm{~km})$. 


\subsection{Stochastic generation of input data for A2/B2 runs}
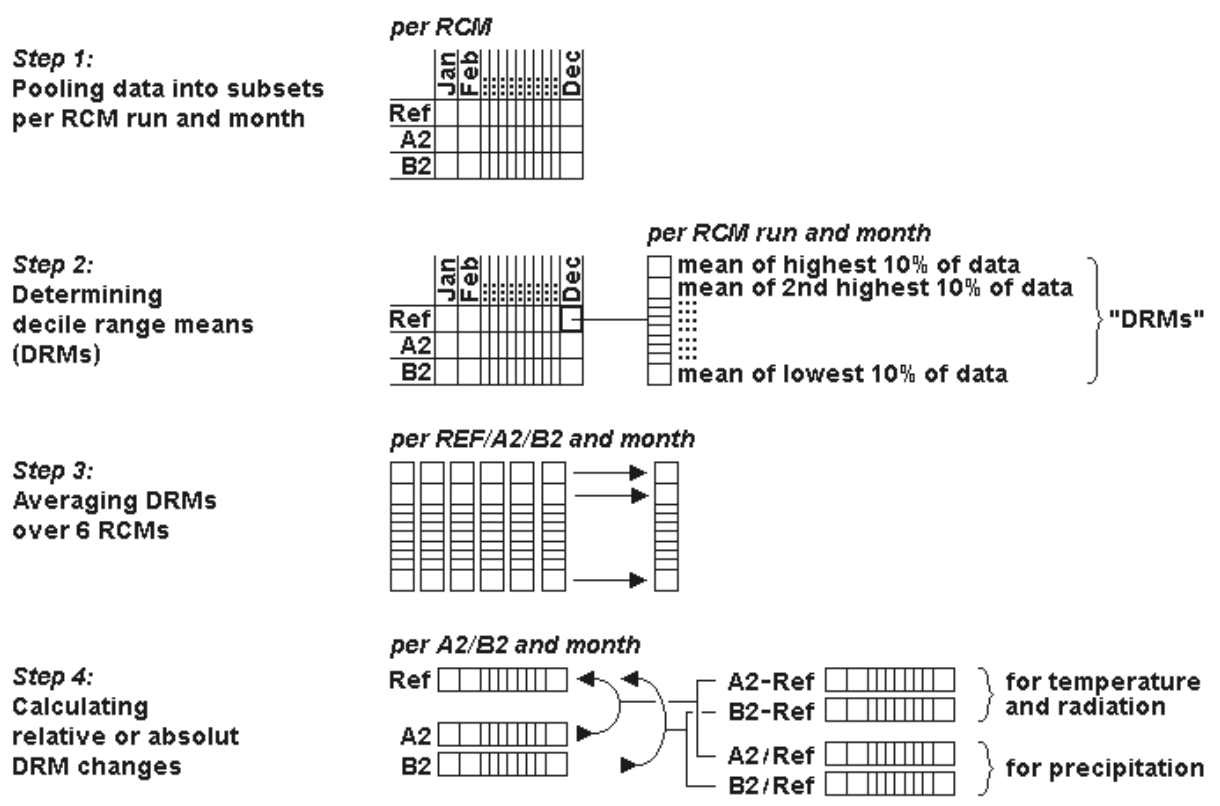

Figure 6: Schematic of determining month-, scenario-, and decile rangespecific changes in temperatures, precipitation and radiation between reference and future period.

We modified the observed data series of precipitation, longwave radiation and temperature to represent climatic conditions towards the end of the 21st century by largely following the methods described in López-Moreno et al. (in press): First, daily incoming longwave radiation data were pooled into $12 \times 3 \times 6$ subsets according to 12 months, 3 projections (Ref, A2, B2), and 6 Regional Climate Models (Fig 6, Step 1). Each of these 216 subsets was further subdivided into decile ranges (i.e. the lowest, secondlowest ... highest $10 \%$ percent of data) of which we determined the mean value (Fig 6, Step 2). These 2160 Decile Range Mean (DRM) values were then averaged for the six RCMs resulting in $12 \times 3$ DRM vectors (Fig 6, Step 3). Finally, to characterize the predicted changes between current and future climate we subtracted the DRM vectors for each scenario with their respective counterparts from the reference runs (Fig 6, Step 4). The resulting vectors on DRM changes (A2-Ref and B2-Ref, Figure 7) were used to adapt the observed data to represent future climate: first, the measured longwave radiation data were pooled into monthly data subsets. Then, for each of the 12 subsets we calculated decile ranges and assigned each measured values to its decile range. Finally, using the vectors on DRM changes as a look- 

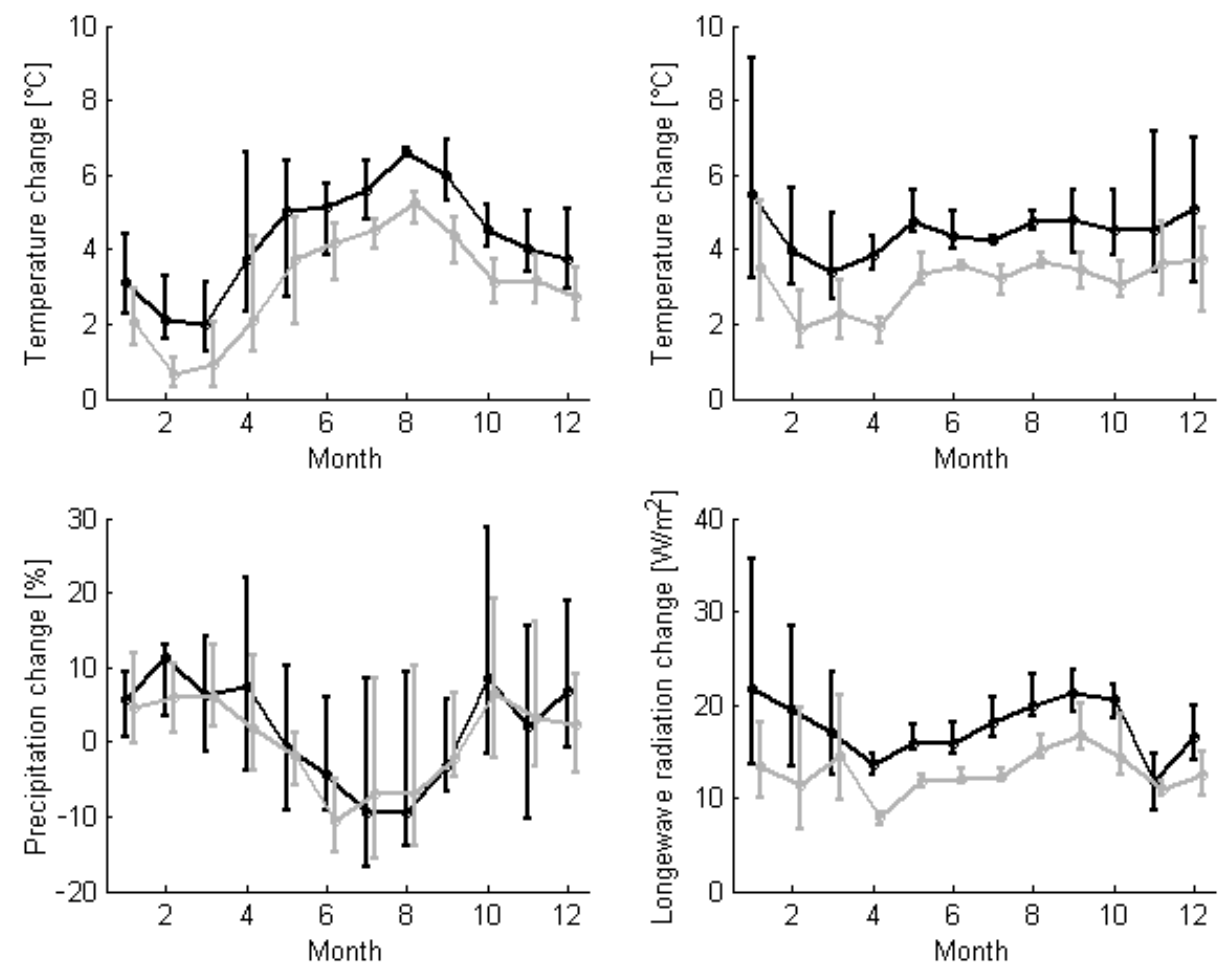

Figure 7: Predicted changes in daily minimum temperature (top left), daily maximum temperature (top right), precipitation (bottom left) and longwave radiation (bottom right) according to scenario A2 (black) and scenario B2 (gray). The center lines show the average change between future and control period, the top whisker denotes respective changes for the highest decile range, and the bottom whisker denotes respective changes for the lowest decile range. 
up table, each measured value could be offset specifically for each month, scenario, and decile range.

To modify the precipitation data we mainly applied the same method as for longwave radiation, with three exceptions: firstly, we determined DRM values from daily sums instead of daily averages; secondly, we described the changes between future and reference climate in terms of DRM quotients instead of DRM differences; and thirdly, only daily precipitation sums greater than zero were accounted for. This includes decile ranges, which were only calculated on data with precipitation sums greater than zero.

As temperature features a considerable daily cycle, we extended the methodology described above (see longwave radiation) to additionally account for potential changes in the spread between daily minimum and maximum temperature. We therefore calculated DRM changes separately for simulated daily minimum and maximum temperatures. They were then used to adapt the lowest and highest temperature value for each day in the observed data series (hourly resolution). Intermediate values were finally adapted by linearly interpolating the offset used for adjacent minimum and maximum temperature values.

Finally, the manipulated data series containing precipitation, longwave radiation and temperature data were interpolated over the model grid according to the procedures described above for the reference run.

\subsection{Presentation of the results}

Since this study focuses on general trends, it has been decided that most of the results would be presented as yearly averages, resulting in more condensed figures. The modelling has been performed for each year of the period of interest, and the outputs have been averaged to compute the general trends of an average year according to the chosen scenario (from 08/2000 to 08/2006 for the Dischma catchment and from $08 / 2001$ to $08 / 2006$ for the Inn catchment). Therefore, year to year variability is smoothed in the results presented.

\section{Results and discussion}

The purpose of this paper is to assess the projected changes in snow cover and runoff for two catchments. We chose to define the current status as the six year average from 2000/2001 to 2005/2006 for the Dischma and the five year average from $2001 / 2002$ to $2005 / 2006$ for the much larger Inn catchment. 


\subsection{Verification}

The hydrological model in the form used here and its verification against satellite snow cover area and runoff data were first described by Lehning et al. (2006) for the Dischma catchment. Their application focused on model presentation and investigated the influence of vegetation and an accurate radiation transfer treatment of snow and runoff. Model verification was provided by comparison with satellite snow covered area and by comparison with measured runoff. Alpine3D has also recently been used for glaciated catchments (Michlmayr et al., in press; Magnusson et al., submitted) and has shown a good performance.

In order to explore the reliability of the method used in this study, a reference Alpine3D run was defined using unmodified meteorological input. The outputs of this reference run were compared to measurements in order to check the accuracy of the simulation. Two parameters were examined: the snow cover and the catchment discharge. Since the Inn catchment is heavily regulated, such a comparison could only be performed for the Dischma catchment, which also offers a higher density of snow cover measurements. Having a more extensive comparison of simulated snow covered area with satellite information has been attempted but was unsuccessful because of the low quality and coarse resolution of the satellite products available.

\subsubsection{Snow cover measurements}

The snow cover simulation was verified using several snow height point measurements that were compared to the simulated snow heights. The simulated snow height is actually the snow height of the cell that contains the location of the snow station, meaning that any subgrid variations in the snow cover that would impact the snow height measurement can be problematic. The snow height experimental measurements also have problems however: the sonic snow height sensors occasionally return a very noisy signal (especially during snow events) and manual snow height measurements could depend on the observer making the measurement.

The Figure 8 shows the comparison between modelled and measured snow heights at three locations, with three different measurements methods. The first one, Stillberg, is located in a N-NE slope $\left(28^{\circ}\right)$ at $2131 \mathrm{~m}$ a.s.l. This station has automatic snow height measurements using an ultrasonic sensor and the data is filtered in order to remove noise. The second one, Teufi, is located on the valley floor of the Dischma catchment at $1702 \mathrm{~m}$ a.s.l., below the Stillberg station, on flat terrain. This is a manual snow station, with daily measurements. This station has no data for year 2006. Finally, the third 

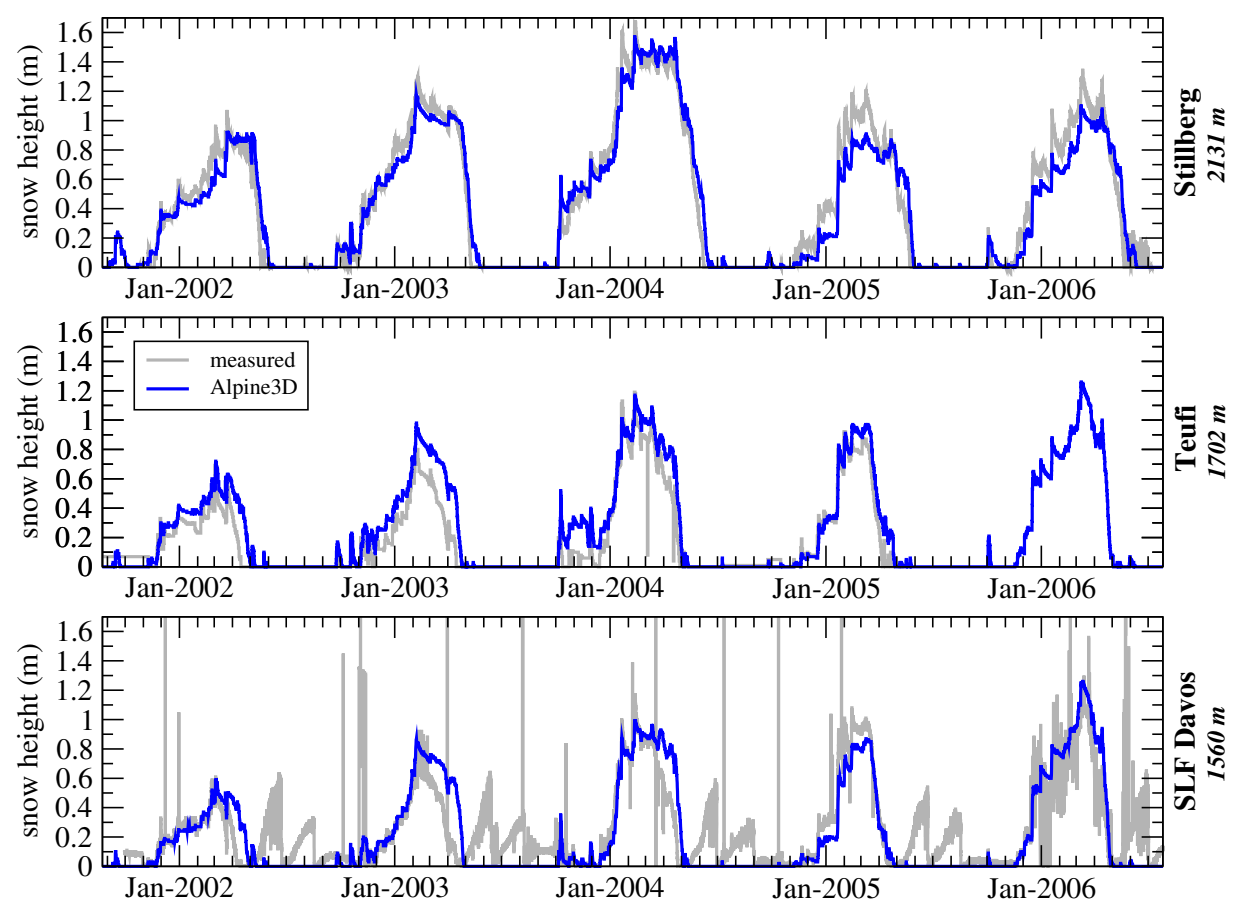

Figure 8: Comparison between measured (automatic Stillberg station, automatic SLF, Flüelastrasse station, manual Teufi station) and modelled snow heights for the Dischma catchment, for the winters 2002 to 2006. 
station, SLF, Flüelastrasse, is located on flat terrain at $1567 \mathrm{~m}$ a.s.l. on the valley floor of Davos. This station has automatic snow height measurements using an ultrasonic sensor but its data is not filtered. The spikes (mostly occuring during snow fall events) are clearly visible, the vegetation growth (Jonas, 2008) and mowing are also visible in summer. This station is not compared against data from the same location in the simulation because it is slightly outside the simulation domain. The simulated data comes from a cell located $400 \mathrm{~m}$ to the south, at the same elevation and also on flat terrain on the valley floor.

The comparison between the measured and the simulated data shows the model to be in reasonable agreement with the measurements. The Stillberg station has a slightly better agreement than the other stations, which may be derived from the fact that this station contributes to the meteorological input (which of course does not include snow depth). At the end of the season the model overestimates the snow heights at lower elevation stations for winters 2002 and 2003 while the correct snow depth is modelled for winters 2005 and 2006. Nevertheless, this comparison builds confidence that this modelling approach can be used from studying trends of climate change impact on snow cover.

\subsubsection{Discharge}

For the Dischma catchment, the simulated discharge is compared to the measured flow at the gauging station Dischma Kriegsmatten (1668 m a.s.l.). Precipitation (monthly and weekly average) is shown together with simulated (reference) and measured discharge in Figure 9. The monthly and weekly precipitation rates were calculated from hourly measurements made at the Weissfluhjoch station located $4 \mathrm{~km}$ north of the Dischma catchment outlet, at an altitude of $2537 \mathrm{~m}$ a.s.l. A daily average discharge is also provided as a basis for averaging over the years.

Note that the discharge simulation was made with generic parameters for the runoff module, as in Lehning et al. (2006). These parameters are based on estimated reservoir sizes for the conceptual sub-surface routing. A better match between observed and simulated discharge could certainly be obtained by a parameter calibration on each catchment. This appears to be inappropriate for the current application for two reasons. Firstly, since the Inn catchment is heavily managed for hydro-power generation, a calibration procedure is impossible there and standard parameters therefore have to be used. It is then consistent to use standard parameters for Dischma, too. Secondly, a calibration could mask model problems and since Alpine3D is constructed to rely on physical process representation, a calibration contra- 


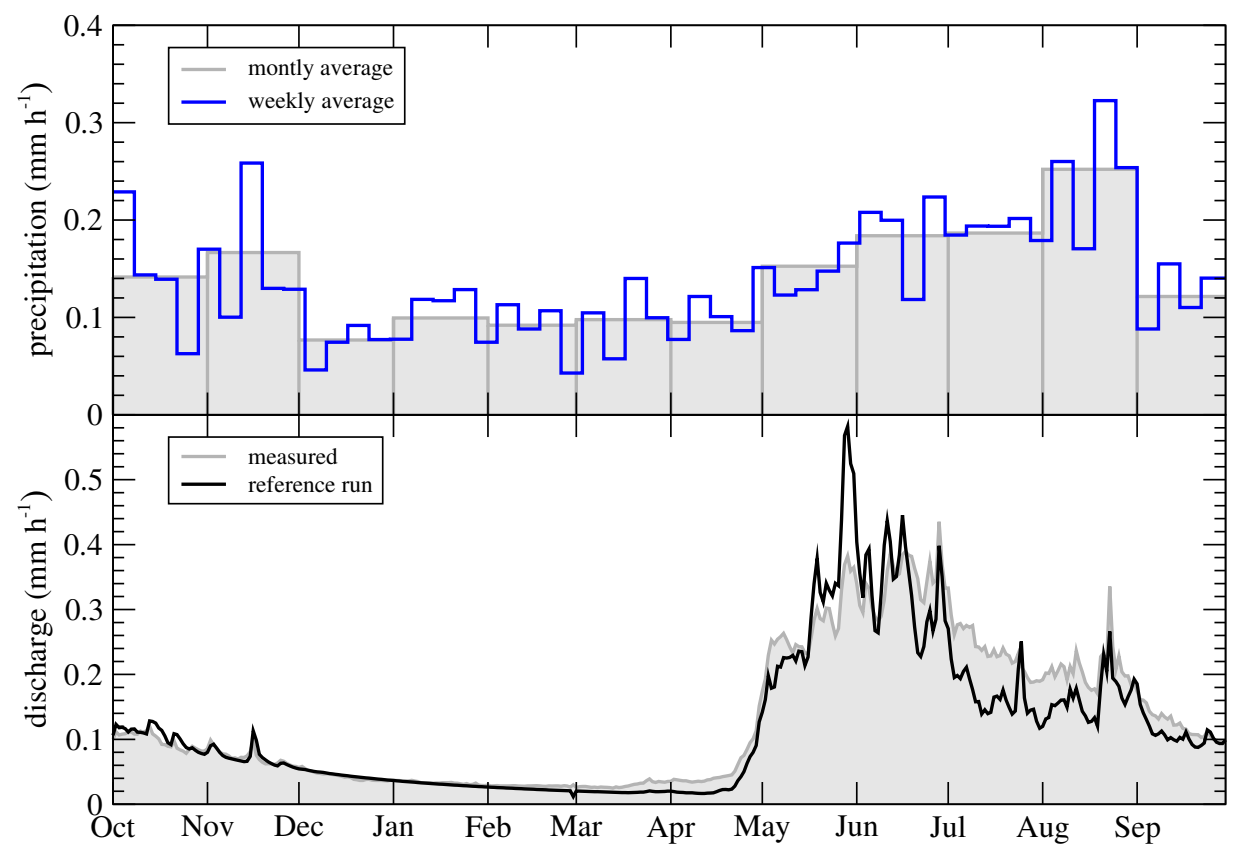

Figure 9: Comparison between measured and modelled daily discharge for the Dischma catchment, averaged over the winters 2001 to 2006.

dicts this model principle.

One possible model problem is apparent from Figure 9: the spring peak snow-melt discharge is overestimated, while this is compensated by an underestimation of discharge during the summer (smaller but longer lasting). The reason for this could be a false assumption of sub-surface reservoirs in the runoff module. A known weakness of Alpine3D, which could also add to this problem, is that too much snow is usually simulated in steep terrain at high altitudes, especially if the model is run without the drifting snow module. The fact that in reality little snow is deposited in steep rock walls is not captured by the model. Additionally, Alpine3D cannot recognize very steep slopes as they are smoothed according to the resolution of the digital elevation model.

The overall nature of the discharge is, however, satisfactorily captured by Alpine3D. We judge the discharge simulation to be sufficiently accurate to proceed with climate change simulations. Note that the Inn discharge profile is qualitatively similar to the Dischma discharge under the current climate, although the valley is dryer (Figure 4). 


\subsection{Results}

\subsubsection{Snow cover changes}

First we will discuss the snow distribution in the catchments: Figure 10.a shows the distribution of snow for the current climate. The average snow water equivalent for each altitude band is represented as a function of the time of the year. Note that the snow cover in recent years has already visibly decreased compared to pre 1980 (Marty, 2008). Under the current climate, the transition between marginal and dominant snow cover appears to be around $2000 \mathrm{~m}$ a.s.l. Above this altitude, snow is present 9-10 months per year.

The average snow distribution for scenario runs A2 and B2 are provided in Figures 10.b and 10.c. The average snow water equivalent for each altitude band as a function of the time of the year changes dramatically in both scenarios and for both catchments (Dischma and Inn). At all elevation ranges the maximum snow water equivalent and the duration of a significant snow cover would be reduced. The reduction in snow would be even more severe under the A2 scenario.

When looking at timing and magnitude of the peak snow water equivalent, we arbitrarily introduce two classes: above and below $2000 \mathrm{~m}$ a.s.l. For the lower elevation of the Dischma catchment, we can observe that the peak in snow water equivalent shifts by 36 days from April 11 to March 6 in the A2 scenario and by 28 days from April 11 to March 14 in the B2 scenario. The maximum snow water equivalent is reduced by $47 \%$ and $36 \%$ in the A2 and B2 scenarios, respectively. For the higher elevation, the change would be similar (44\% and $29 \%$ for the two scenarios) but the time shift would be less pronounced (16 and 7 days respectively). It is interesting to note that the changes in the A2 scenario would roughly correspond to shifting the reference simulation down by 900 meters for both catchments. The numbers for the Inn catchment are similar for the maximum snow water equivalent reduction, but the trends on the time shift are opposite, seing a slightly increased shift for the higher altitudes compared to the lower altitudes (15 days above $2000 \mathrm{~m}$ compared to 7 days below $2000 \mathrm{~m}$ for both scenarios). This is suspected to be the result of the uncertainties of our approach and may be related to the lack of input data representative of the highest elevations for the Inn catchment.

The time of the year at which the last snow disappears in a given altitude band has also been extracted from the simulations and averaged over the simulation period. In order to do so, a $20 \mathrm{~mm}$ Snow Water Equivalent threshold has been arbitrarily defined to be "no snow left". The begining of a new snow season for a given altitude band is defined as the first day from 

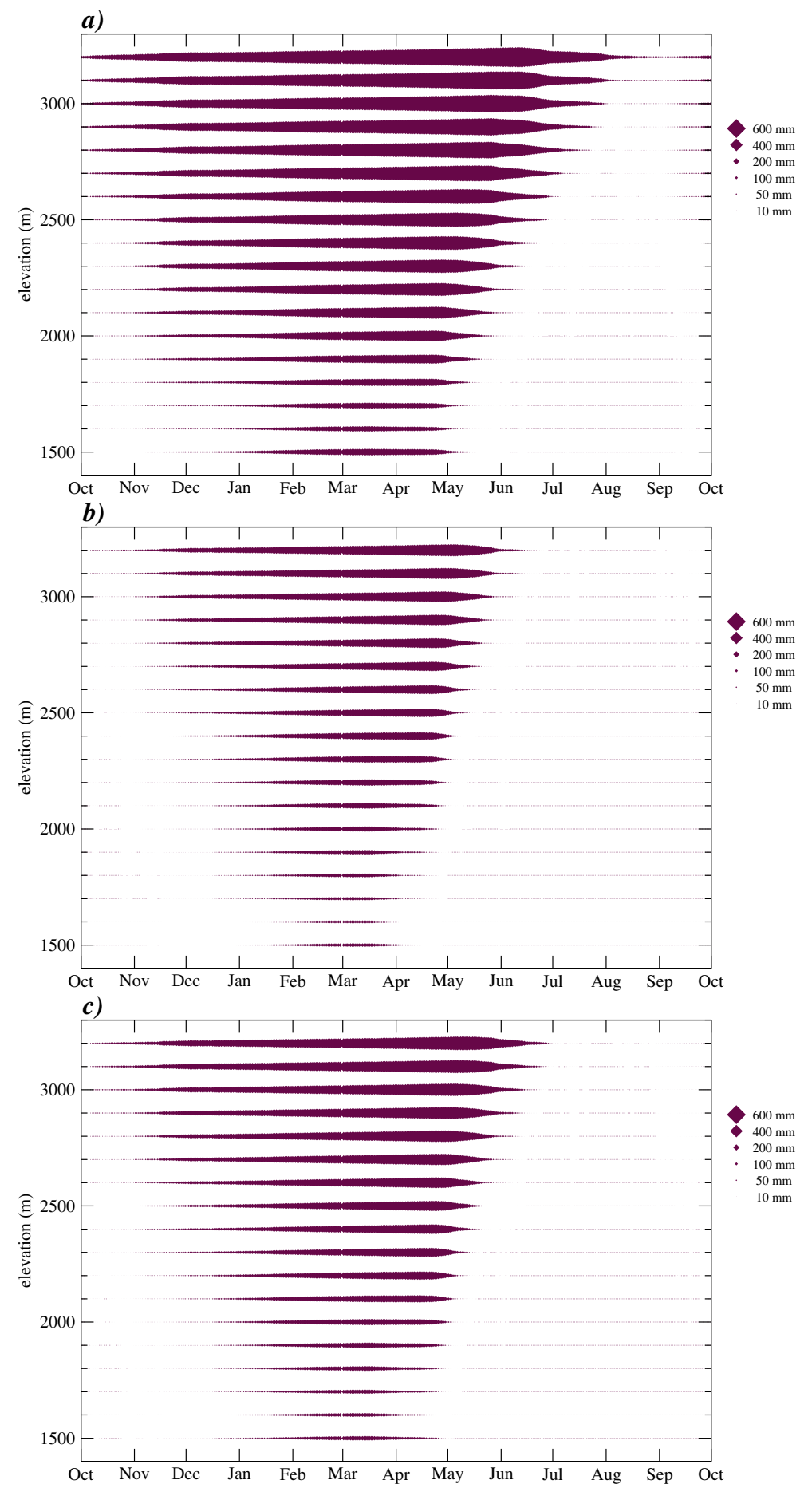

Figure 10: Snow water equivalent in the Dischma catchment for each altitude band, averaged over the winters 2001 to 2006. a) reference, b) scenario A2, c) scenario B2. 

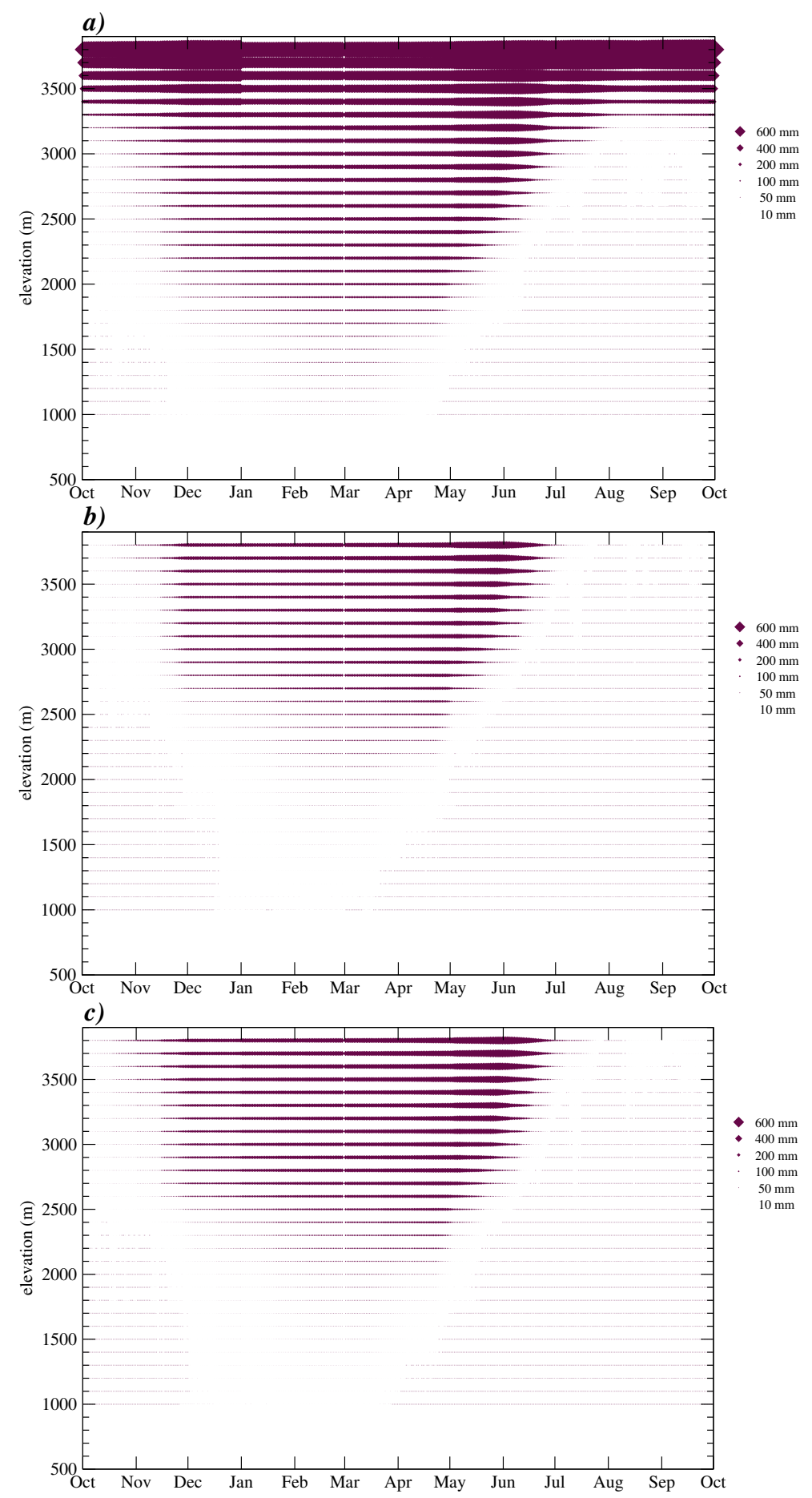

Figure 11: Snow water equivalent in the Inn catchment for each altitude band, averaged over the winters 2002 to 2006. a) reference, b) scenario A2, c) scenario B2. 


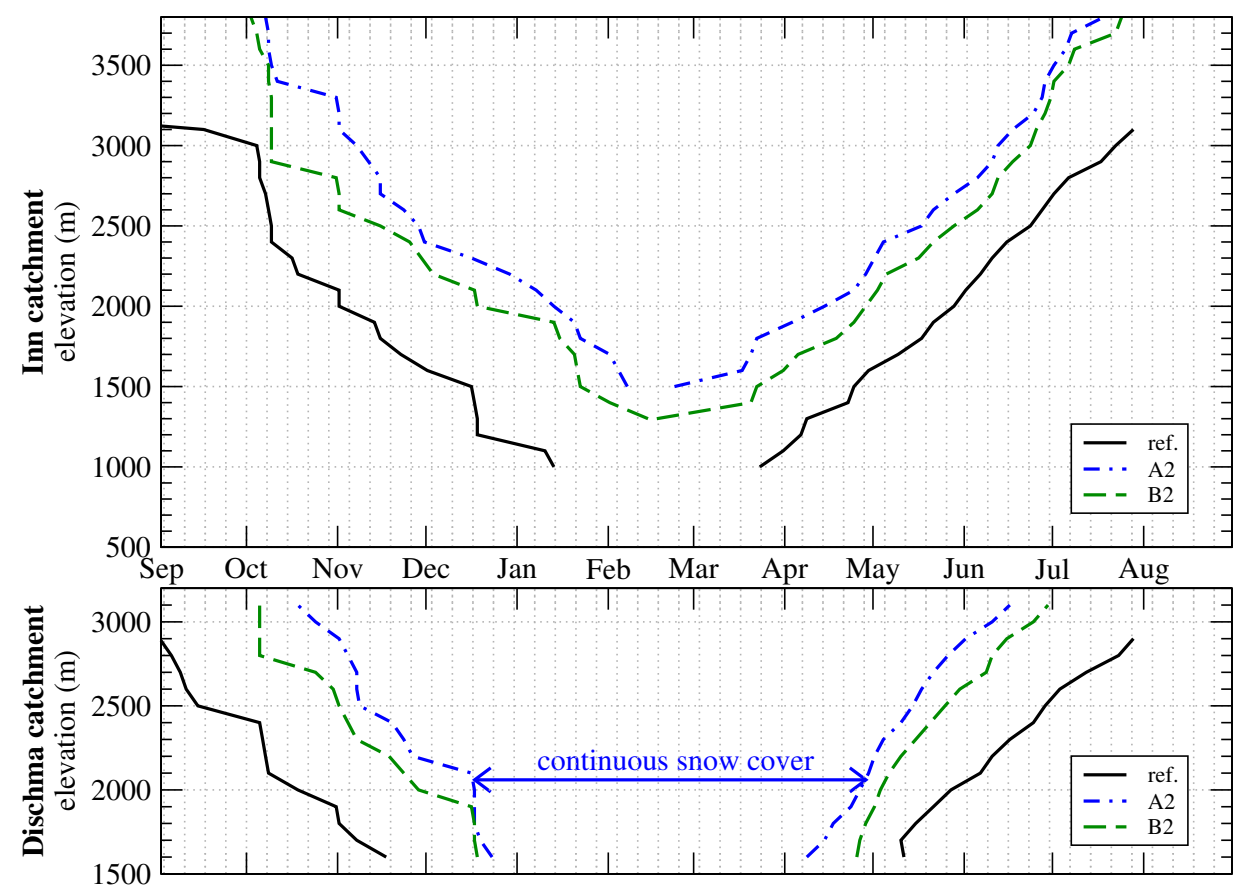

Figure 12: Altitude dependency in the establishment of a continuous snow cover and its melting for the climate scenarios and the reference simulations for the Inn and the Dischma catchments. 


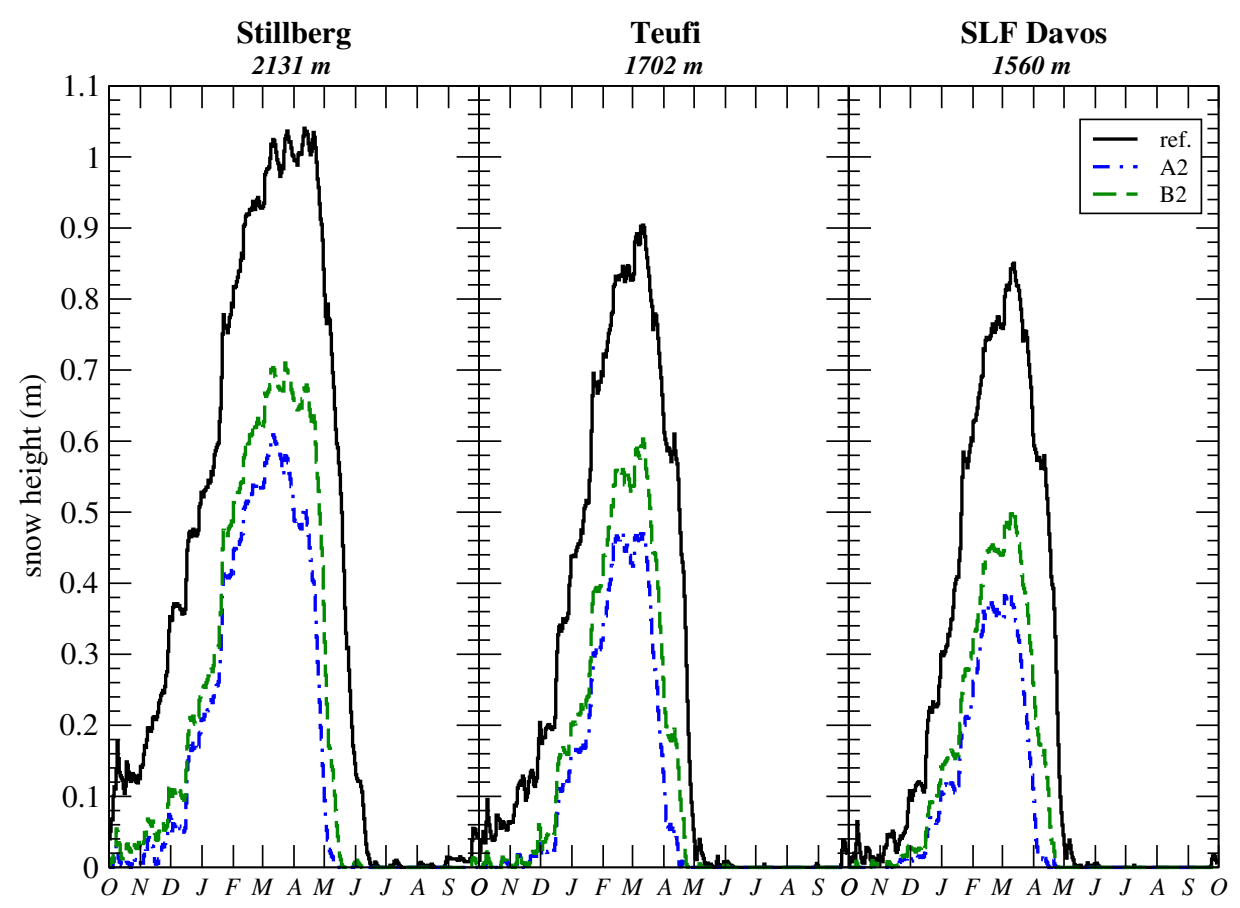

Figure 13: Comparison between average snow depths at three stations between the reference run and scenarios A2 and B2.

which the average snow water equivalent of the entire altitude band never goes below the threshold anymore. The end of the snow season is defined as the first day that sees the average snow water equivalent of the entire altitude band dropping below the threshold. Practically, this means that snow accumulated in a shaded area could significantly contribute to alter the begining and end dates of the snow season for its elevation band. Nevertheless, this definition makes sense from an hydrological point of view as it represents the contributions of a given elevation band to the global discharge of the catchment.

The snow cover duration curve is shown in Figure 12. The reference simulation as well as the climate scenarios have been plotted for comparison. First, the begining of snow season differs between the Inn and the Dischma catchments. It might come from the relatively dry climate of the Inn catchment. This is very visible in Figure 11.a where for a lot of altitude bands the snow season starts during a specific precipitation event at the end of November. The melt phase however, is not significantly affected by precipitation, therefore the two catchments show very similar behavior. Note that the continuous snow cover criteria can never be fulfilled in an average year below $1000 \mathrm{~m}$ a.s.l. (for the reference run), therefore no data is produced for 
these low elevations.

For the Dischma catchment, the two climate scenarios would differ approximately by a constant offset. However, the snow season duration is more affected at higher altitudes. This result on future snow cover temporal patterns differs from the observations on past snow cover patterns made by Marty (2008), who found that altitudes below about $1800 \mathrm{~m}$ have already shown a stronger reaction on observed warming than higher altitudes. Since the Inn simulation does not show such an elevation dependence, the result might again be a consequence of the altitude - exposition distribution in the Dischma catchment. A further reason might be that the strong scenario shifts the altitude band of maximum sensitivity upwards. This is discussed further in the conclusions.

It appears with the predicted warming that permanent snow or ice would no longer be possible in the Dischma or Inn catchments, which is in agreement with the prediction that the few smaller glaciers at these lower altitudes would completely disappear in the Alps (Zemp et al., 2006). The elevations which have the highest area fractions would experience a complete melt approximately 40 days earlier in the A2 scenario and 35 days earlier in the B2 scenario. The highest elevations would experience a 60 or 50 day shift earlier for scenarios A2 or B2, respectively. For the Inn catchment, most altitudes would experience a complete melt approximately 40 days earlier in the A2 scenario.

Finally, the Figure 13 shows the same stations as used for the verification in Figure 8, but now comparing the outputs of the two climate scenarios. The snow season would be shortened as described above, but the snow height would be more affected at lower elevations: the A2 scenario would experience a $40 \%$ reduction of snow height for Stillberg, a $49 \%$ reduction at Teufi and a $54 \%$ reduction at the SLF, Davos station. In the B2 scenario, these would become $30 \%, 33 \%$ and $42 \%$ respectively.

\subsubsection{Discharge}

The changes in snow cover discussed above are consistently represented in discharge changes. Figure 14 shows the measured and simulated discharge in the same format as Figure 9, adding the simulated results of the two climate scenarios A2 and B2 described in section 2.1.

The major change that is visible when comparing the reference simulation discharge and the climate change scenarios discharges is a strong peak in early May in the climate change scenarios not visible in the reference. This is the beginning of snow melt in the catchment, which occurs a month earlier in both scenarios than in the reference case. There are two main observations 

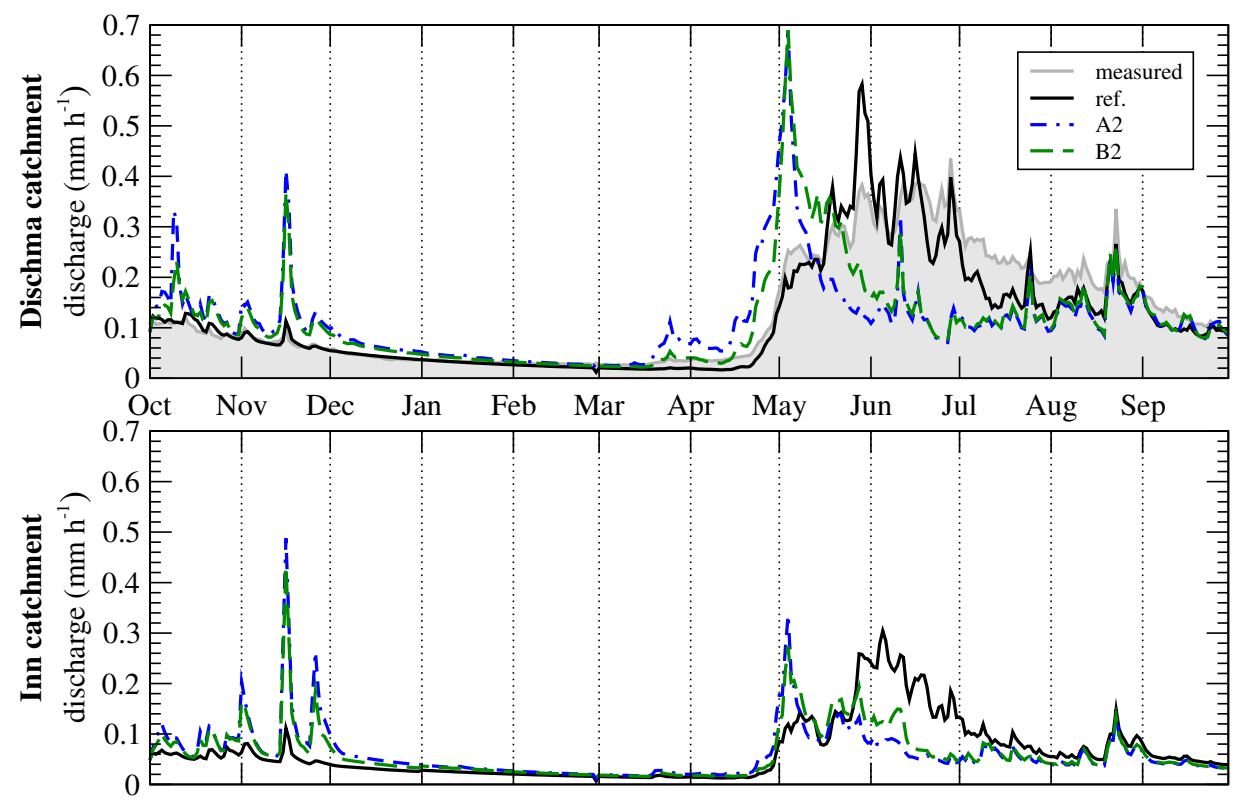

Figure 14: Daily values of discharge at the Dischma and Inn catchments, for the reference and scenario simulations, averaged over the winters 2001-2006, 2002-2006 respectively.

to be made: (i) the snow-melt discharge peak is not only earlier but also more pronounced for the Dischma catchment; (ii) the higher snow melt peak is more concentrated in late spring / early summer, while it is spread over a longer period under the current climate. This means that snow contributes to the discharge over a much shorter time but at the same time the probability of spring flooding might increase. The two scenarios are qualitatively similar, yet showing differences in the magnitude of snow-melt discharge. The two scenarios merge again in June, indicating the time at which the influence of snow melt on discharge becomes negligible in the catchment for both scenarios. Over the summer, discharge is then determined by rainfall. In contrast, the reference run shows snow influence on discharge until early August - discharge from snow therefore being significant for a large part of the year.

For the Inn catchment, the spring discharge peak is not as pronounced as for the Dischma. The Inn catchment being much dryer than the Dischma catchment, particularly in winter, the spring discharge depends on snow built-up during late fall. Since in the A2 scenario these precipitation events occur as liquid precipitation for a much larger fraction of the altitudes, there is less snow available to melt in spring. Therefore, despite an earlier and shorter melt period for the Inn catchment, there is no increase in the 
amplitude of the spring discharge. Moreover, the lowest elevations are not able to build up a snow pack anymore and thus can not contribute to the discharge in the spring. This is in contrast to the Dischma simulation which contains a much narrower range of elevations, hence the fraction of snow free altitude bands is insignificant. Finally, the more consistent distribution of exposure in the Inn simulation means that shading effects do not have a strong impact on the discharge (a given altitude band melts more uniformly) compared to the Dischma catchment (as shown in Figure 3).

Another feature of the data is local discharge peaks in late autumn: in the reference simulation, for both catchments, the precipitation events at that time of the year produce snow down to $1600 \mathrm{~m}$ a.s.l., not leading to a significant discharge increase. In the climate change scenario, no snow is seen below $2200 \mathrm{~m}$ a.s.l. and significant discharge peaks are created. Again, since the Inn catchment contains a significant proportion of low elevations, this effect is amplified and might increase the risk of flooding.

\subsection{Limitations}

\subsubsection{Climate models}

The meteorological input data for the Alpine3D future snow cover simulations was derived from observed data outside the RCMs reference period. Better practice would have been to have a model run driven by observed data within the RCMs' reference period. This would have been possible but at the expense of losing the spatial resolution of input data, i.e. losing 9 out of 10 stations for the Dischma run. This is because the monitoring network IMIS which was founded in 1998, only achieved a reasonable station density around 2002. Hence for the reference run we chose a period (2002-06) slightly after the RCM reference period (1961-90) assuming this would be still reasonably close to the reference period if compared to the 2071-2100 period. Applying shifts in meteo variables stemming from simulations of two periods 110 years apart to describe snow cover changes over a 90 year period might lead to a slight overestimation of predicted changes. However, this problem should be partly mitigated, if - as expected - climate change will become more pronounced towards the second half of the century.

We also chose to combine the climate change predictions from $6 \mathrm{RCMs}$ to stipulate at least 4 numerical experiments (2 scenarios, 2 catchments) as it would not have been possible to run 24 numerical experiments due to computational constraints. Therefore we cannot discuss the influence of uncertainties in the input data on variation in the output results. However, using 2 scenarios (SRES A2 \& B2) allows at least some basic consideration 
of uncertainty in the driving data.

\subsubsection{Alpine3d limitations}

This study uses Alpine3D to predict snow cover changes and associated changes in discharge based on climate change scenarios. In addition to the uncertainties coming from the climate change calculations, this introduces uncertainties related to the model, which are discussed here. (i) A major weakness of any such study is that the climate change scenario data are a priori inconsistent with the result of the physical downscaling. The example of the snow cover is very illustrative in this context. While most climate models use a very simplified snow description and are not able to resolve smaller scale topography in the mountains because of their coarse resolution, the downscaling produces a much more detailed snow representation, which must therefore be locally inconsistent with the climate model. In our study we assume that the stochastic method of applying changes in the forcing parameters to locally measured time series is a reasonable way to deal with this inconsistency. (ii) A second source of uncertainty is the interpolation of meteorological fields necessary to drive Alpine3D. While the input fields are based on local measurements as described above, the resolution of the stations is still insufficient to represent the small scale variation of weather in such mountainous terrain. Therefore, the predictions of the local snow cover dynamics represent the error from the interpolation of weather input. While the absolute error arising from this may be quite large, the uncertainty should be limited as far as the assessment of change is concerned. Nonetheless this is considered to be a significant yet hard to quantify source of uncertainty. (iii) For the scale investigated here, lateral transport of snow through wind and avalanches has been neglected. This error is also thought to have more influence on the absolute amount of snow present at a grid point than for a prediction of change. (iv) The one-dimensional energy and mass balance of SNOWPACK is thought to be very accurate and a minor source of error. This has been validated for many climates worldwide and the change simulations should not therefore have a major uncertainty derived from this. (v) The conceptual runoff part is only responsible for the sub-soil water movement and should therefore also be robust for our climate change simulations. 


\section{Conclusions and implications}

In this paper we presented model simulations of climate change impact (scenarios A2 and B2) on snow and runoff in two Alpine catchments. The two catchments, Dischma and Inn, have different sizes $\left(43 \mathrm{~km}^{2}\right.$ and $1945 \mathrm{~km}^{2}$, respectively) and different characteristics. Both represent rather dry innerAlpine conditions with the Inn catchment being very dry and the Dischma catchment being climatologically at the transition between the wetter north and the dryer Inn valley.

It has been shown that even with very different catchment sizes, the response of the runoff and snow cover to the climate change scenarios is qualitatively similar. On the other hand, the distribution of altitudes in a given catchment has a strong quantitative influence on the runoff: catchments whose elevation range is mostly centered around the current snow line are experiencing the most changes in these scenarios. In this context, we also looked at the sensitivity of snow cover duration to an increase in temperature, similar to what Hantel and Hirtl-Wielke (2007) define as sensitivity of the Alpine snow cover (not shown). For the two catchments investigated no clear trend (or a clear local maximum) of this sensitivity could be found, probably because of two reasons: (i) the joint distribution of altitude and exposition will mask such a trend for the limited size of catchment investigated here; and (ii) the strong changes in the two scenarios will lead to a shift of the zone of maximum sensitivity as described by Hantel and Hirtl-Wielke (2007) over several altitude bands. This sensitivity will however be further investigated in future.

The most prominent finding is that the mountains in the south-east of Switzerland would no longer support a permanent snow cover and that glaciers would therefore disappear, if our model assumptions discussed above are justified. The changes in snow cover would generally be significant and comparable to a shift in altitude of up to $900 \mathrm{~m}$. The runoff would also be heavily affected. The current regime of having a significant part of the annual runoff shaped by snow melt would change to a regime where snow melt would occur during a short time in late spring, producing a large but short runoff peak. This new regime may be problematic regarding water resource management in the dry inner-alpine valleys and may also increase the risk of flooding from rain on snow events.

In the future, we plan to eliminate known weaknesses of Alpine3D, such as the errors introduced by spatial interpolation of the meteorological fields and the bias towards too much snow on steep slopes in high altitudes. We will also use Alpine3D to investigate individual components of the hydrological balance as a function of the climate change scenarios. We therefore plan to be 
more rigorous about the stochastical climate generation for the local catchments and to look at individual drivers of climate change such as changes in snowline, changes in melt and changes in precipitation. Additionally, we will be aim to understand the changes in soil moisture and evaporation. Not much work has been done on evaporation from snow surfaces and the changes in snow cover will also result in changes of evaporation patterns.

\section{Acknowledgments}

This work is partly supported by the Swiss National Science Foundation, the European Community (AWARE), and the ETH Competence Center for Environment and Sustainability (CCES). Many individuals have been helping with the ALPINE3D development and provided general support. We thank Marcia Phillips, Christoph Marty and Nicholas Dawes for their proof-reading and Christoph Marty and Peter Bebi for their Stillberg data. The regional climate models were provided through the PRUDENCE data archive, funded by the EU through contract EVK2-CT2001-00132. The Federal Office of Meteorology and Climatology MeteoSwiss provided some of the meteorological measurements. The Swiss Federal Office for Environment provided the discharge data. Two reviewers helped to improve the paper significantly with their very detailed and constructive comments.

\section{References}

[1] Barnett, T.P., Adam, J.C., Lettenmaier D.P. Potential impacts of a warming climate on water availability in snow-dominated regions Nature, 438, 303-309, doi:10.1038/nature0414. 2005

[2] Bartelt. P.B., Lehning M. A physical SNOWPACK model for Avalanche Warning Services. Part I: Numerical Model Cold Reg. Sci. Technol., 35/3, 123-145. 2002

[3] Blöschl, G., Kirnbauer, R. and Gutknecht D. Distributed Snowmelt Simulations in an Alpine Catchment. 1. Model Evaluation on the Basis of Snow Cover Patterns, Water Resources Research, 27(12), 3171-3179. 1991

[4] Christensen, JH. Carter, TR. Rummukainen, M. Amanatidis, G. Evaluating the performance and utility of regional climate models: the PRUDENCE project. Climatic Change 81, 1-6. 2007 
[5] Fierz, C., P. Riber, E.A. Adams, A.R. Curran, P.M.B. Föhn, M. Lehning and C. Plüss Evaluation of snow-surface energy balance models in alpine terrain. J. Hydrol., 282, 76-94. 2003

[6] Garen, D., and Marks D. Spatial fields of meteorological input data including forest canopy corrections for an energy budget snow simulation model. In: Dolman, A.J., Hall, A.J., Kavvas, M.L., Oki, T. and Pomeroy, J.W. (Eds.). Soil-Vegetation-Atmosphere Transfer Schemes and Large Scale Hydrological Models, IAHS Publication No. 270, 349-353. 2001

[7] Gurtz, J., Zappa, M., Jasper, K., Lang, H., Verbunt, M., Badoux, A., Vitvar T. A comparative study in modelling runoff and its components in two mountainous catchments. Hydrological Processes, 17, 297-311. 2003

[8] Hagg, W., Braun, L.N., Kuhn, M., Nesgaard, T.I. Modelling of hydrological response to climate change in glacierized Central Asian catchments. Journal of Hydrology, 332, 40-53. 2007

[9] Hamlet, A.F., Mote, P.W., Clark, M.P., Lettenmaier, D.P. Effects of temperature and precipitation variability on snowpack trends in the western United States Journal of Climate, 18, 4545-4561. 2005

[10] Horton, P. Schaefli, B. Mezghani, A. Hingray, B. Musy, A. Assessment of climate-change impacts on alpine discharge regimes with climate model uncertainty. Hydrological Processes, 20, 2091-2109. 2006

[11] Jonas, T., Rixen Ch., Sturm, M., Stoeckli, V. How alpine plant growth is linked to snow cover and climate variability Journal of Geophysical Research, 113, G03013, doi:10.1029/2007JG000680. 2008

[12] Knowles, N., Dettinger, M.D., Cayan, D.R. Trends in snowfall versus rainfall in the Western United States Journal of Climate, 19, 18, 4545-4559. 2006

[13] Landl, BM., Lehning, M. Evaluation of coupled model simulations of energy balance over a snow covered at eld and a steep slope in Alpine terrain. Water Resources Res. In review

[14] Lehning, M., Bartelt, P., Brown, R.L., Russi, T., Stöckli, U., Zimmerli, M. Snowpack Model Calculations for Avalanche Warning based upon a new Network of Weather and Snow Stations. Cold Reg. Sci. Technol., 30, 145157. 1999 
[15] Lehning, M, Bartelt, P.B., Brown, R.L., Fierz, C., Satyawali, P. A physical SNOWPACK model for the Swiss Avalanche Warning Services. Part III: Meteorological Boundary Conditions, Thin Layer Formation and Evaluation, Cold Reg. Sci. Technol., 35(3), 169-184. 2002

[16] Lehning, M., Volksch, I. Gustafsson, D. Nguyen, TA. Stahli, M. Zappa, M. ALPINE3D: a detailed model of mountain surface processes and its application to snow hydrology. Hydrological Processes 20, 2111-2128. 2006

[17] Lehning, M., Löwe, H., Ryser, M., Raderschall, N. Inhomogeneous precipitation distribution and snow transport in steep terrain. Water Resources Res., doi:10.1029/2007WR006545. 2008

[18] López-Moreno, J.I., Goyette, S., Beniston, M., Alvera, B. Sensitivity of the snow energy balance to climate change: Implications for the evolution of snowpack in Pyrenees in the 21st century. Climate Research. in press

[19] Luetschg, M., Lehning, M., Haeberli, W. A sensitivity study of factors influencing warm/thin permafrost in the Alps J. Glaciol., in press. 2008

[20] Magnusson, J., Jonas, T., Lòpez-Moreno, I., Lehning, M. Potential impact of climate change on the snowpack in a partly-glaciated basin in central Switzerland. Nordic Hydr. in review

[21] Marty, C. Regime shift of snow days in Switzerland. Geophysical Research Letters 35, L12501, doi:10.1029/2008GL033998. 2008

[22] Michlmayr, G., Lehning, M., Holzmann. H., Koboltschnig, G., Mott, R., Schöner, W., Zappa. M. Application of Alpine3D for glacier mass balance and runoff studies at Goldbergkees, Austria Hydrol. Processes, in press., doi:10.1002/hyp.7102/. 2008

[23] Nakicenovic, N. Grübler, A. McDonalds, A. Global Energy Perspectives. Cambridge University Press, 299 pp. 1998

[24] Nishimura, K., Baba, E., Hirashima, H., Lehning, M. Application of SNOWPACK model to snow avalanche warning in Niseko, Japan Cold Reg. Sci. Technol., 43, 62-70. 2005

[25] Ohmura, A. Physical basis for the temperature-based melt-index method. J. Applied Meteorology, 40, 753-761. 2001

[26] Raderschall, N., Lehning, M., Schär, C. Fine scale modelling of the boundary layer wind field over steep topography. Wat. Res. Res., in press. 2008 
[27] Rasmus, S., Räisänen J., Lehning, M. Estimating snow conditions in Finland in the late $21^{\text {st }}$ century using the SNOWPACK model with regional climate scenario data as input Ann. Glac., 38, 238-244. 2004

[28] Shepard, D. A two-dimensional interpolation function for irregularlyspaced data. Proceedings of the 1968 ACM National Conference. 517-524. 1968

[29] Singh, P., Kumar, N. Impact assessment of climate change on the hydrological response of a snow and glacier melt runoff-dominated Himalayan river. Journal of Hydrology, 193, 316-350. 1997

[30] Stahl, K., Moore, R.D., Shea, J.M., Hutchinson, D., Cannon, A.J. Coupled modeling of glacier and streamflow response to future climate scenarios. Wat. Res. Research, 44, doi:10.1029/2007WR005956. 2008

[31] Stewart, I.T., Cayan, D.R., Dettinger, M.D. Changes toward earlier streamflow timing across western North America Journal of climate, 18, 8, 1136-1155 2005

[32] Walter, M.T., Brooks, E.S., McCool, D.K., King, L.G., Molnau, M., Boll, J. Process-based snowmelt modelling: does it require more input data than temperature-index modelling? Journal of Hydrology, 300, 65-75. 2005

[33] Zappa, M., Pos, F., Strasser, U., Warmerdam, P., Gurtz, J. Seasonal water balance of an Alpine catchment as evaluated by different methods for spatially distributed snowmelt modelling. Nordic Hydrology, 34, 179202. 2003

[34] Zemp, M. Haeberli, W. Hoelzle, M. Paul, F. Alpine glaciers to disappear within decades? Geophysical Research Letters 33, 4. 2006 